\title{
QC-CE-PYRAMID MODEL IN THE DESIGNING OF THE INFORMATION SYSTEM WITHIN A COMPANY
}

\author{
Violeta Chepujnoska ${ }^{1}$, Elizabeta Mitreva ${ }^{2}$, Gjorgji Chepujnoski $^{3}$ \\ ${ }^{1}$ Faculty of Technology and Metallurgy, "SS Cyril and Methodius” Universit, \\ P. O. Box 580, MK-1001 Skopje, Republic of Macedonia \\ ${ }^{2}$ Factory for Ril Vhicle, Veles, Republic of Macedonia \\ ${ }^{3}$ Faculty of Economics, "SS Cyril and Methodius" University, Skopje, Republic of Macedonia \\ vioche@mt.net.mk
}

\begin{abstract}
The QC-CE-PYRAMID model (Quality Circle and Cause and Effect in the pyramid's structure) represents an excellent foundation for designing an efficient information system of quality. All of the business processes can be standardized with standard operative procedures in form of flow charts. This is sublimed in the QC-CE-pyramid model. The standard operative procedure starts with planning the activity and entering data which give information on the initial state. Then, it continues with the activities of the business processes where each phase derives an output data which appears to be an input data for the following operation. In the end, the business process ends with information in form of quality report. According to the pyramid's structure, we can achieve both vertical and horizontal connection among the employees. Thus, the provision of the quality in the company is accompanied by the information flow according to the standard operative procedures. Having this as an initial point, we have analysed the established information system in the Factory for Rail Vehicles in Veles. By making improvements on the system, we also improved its efficiency as well as effectiveness in regard to the quality of information.
\end{abstract}

Key words: standardization; standard operative procedures; information system; control; quality; QC-CE-pyramid model

\section{МОДЕЛОТ QС-СЕ-РYRАМІD ВО ПРОЕКТИРАњЕТО ИНФОРМАТИВЕН СИСТЕМ ЗА КВАЛИТЕТ ВО ПРЕТПРИЈАТИЕ}

\begin{abstract}
Протокот на информациите во една компанија е многу значаен потсистем во системот за обезбедување квалитет. Моделот QC-CE-Pyramide (Quality Circle and Cause and Effect in the pyramid's structure) е добра основа за проектирање на ефективен информациски систем. Идејата за таа појдовна точка произлезе од фактот што преку моделот QC-CE-pyramid можат да се стандардизираат сите деловни процеси во претпријатието преку стандардни оперативни процедури во облик на тековни карти (flow charts). Стандардната оперативна процедура започнува со планираната активност и влезни информации за почетната состојба; продолжува со активностите на деловните процеси и од секоја фаза се добива излезна информација која е влезна за наредната операција; на крајот, деловниот процес завршува со информација во облик на извештај за квалитет. Притоа се остварува вертикална и хоризонтална поврзаност помеѓу вработените, според структурата на пирамидата. Така обезбедувањето на квалитетот во претпријатието е проследено со текот на информациите согласно со текот на стандардните оперативни процедури. Поаѓајќ од оваа основа, ние го анализиравме воспоставениот информационен систем во Фабриката за шински возила во Велес и со корекции и негово дополнување, преку пристапот на моделот QC-CE-pyramid, ја подобривме неговата ефективност и ефикасност, во поглед на текот на информациите за квалитет.
\end{abstract}

Клучни зборови: стандардизација; стандардни оперативни процедури; информативен систем; квалитет; модел QC-CE-Pyramid 


\section{INTRODUCTION}

About the influence of the informative systems over the improvement of the quality of the business processes

The computer systems, by their hardware and software components, present a solid base for fast transfer of required information for realization of the company processes which are always linked to the answer of the questions: What?-Who?-How?Where?-When?, as well as to the ones answering Who?-To Whom?, which gives a report for the completed tasks within the company [1].

They provide data for the development of the standardization, zero-defect production and cost analysis as basic pillars of the Total Quality management system (TQM) [2]. Nowadays, these data are kept into organized forms and packages (database) which are computerized, can be searched and used in any time, at any work-place, with a unified goal - to achieve efficient work [3].

Quality improvement presents a systematic effort of function practice of making the action of the business processes, in order to make them [4]:

- effective - to do the right thing;

- efficient - to accomplish tasks on time, with optimal costs of the working processes;

- flexible - ability to respond to customer's requirements.

By redesigning the processes [11], better utilization of the existing technologies can be achieved in order to have better quality products, services and increase in productivity and decrease in costs. The interrelations of the employees and the business processes of the company allow total quality control.

In order to define the conditions during the processes, we need to determine the values of the parameters and variables of the system [5, 6].

Every system in given conditions may generate particular information, especially when a change of the conditions occurs. Information, one being generated - becomes acceptable as needed. This means that the information has to have its autonomous flow, i.e. to be grasped immediately, at the right spot, in the right time.

\section{What is the QC-CE-Pyramid model?}

We suggested the QC-CE model for the first time [7] when we implemented it in the practice of standard operative procedures. The QC-Quality circle is the well-known Deming's Circle of quality, Plan-Do-Check-Act, by which the functions of planning, doing, checking, and acting are connected in the realisation of the all processes. The CE (Cause and Effect) Diagram has been applied in order to allocate the quality responsibilities to all of the employees by answering the questions who, what, how, where, when, and to whom is responsible. At the same time, we faced some issues in regards to the responsibility/irresponsibility of the employees. Namely, the transition of social into private (stock) ownership presupposes important changes of the paradigms regarding the strategic management approach, the new system of values and the system of quality management.

At the same time, the European and the word Market impose the need for a change from quality control towards quality management. Thus, the countries in transition are faced with simultaneous changes in regard to several paradigms:

Socialistic Planned Economy T Democratic Market Economy

I

Social Ownership M M Private Ownership

Quality Control E Quality Management

By conducting the research, we expanded the QC-CE model with the Pyramid [8], not only as a hierarchical structure of responsibilities, but also as a hierarchical structure of the management-team responsibilities. We have implemented the created QC-CE Pyramid-Model [9] in the planning of the information system of quality within the factory for rail vehicles.

\section{EXPERIMENTAL}

Implementation of the QC-CE-pyramid model in the designing of the information system of quality within the factory for rail vehicles

For a successful functioning of the quality informational system, the requirements are as follows [10]:

- greatest possible synchronization of the informational system with the system of making decisions upon every level of management;

- establishment of a unique system of measurements, unique frequency for gathering information;

- unique nomenclature and classification of the information; 
- circular flow of the information: starting information for work - feedback information on what has been achieved;

- independent status of the data-base and a possibility of their dynamic deletion as well as supplementation of new data in the data-base;

- flexible structure of the data-base for a provision of an easy approach to the data. Every data should have personal mark as well as mark of the very content;

- establishing computer commands which will allow transfer of the information from one working unit to another, from one location to another, or from one computer program to another;
- supervision and interaction possibility of the user of the managing system with the data-base;

- creation of line of commands for constitution of printed reports for the required content within the data-base;

- coded system of the users in order to protect the information of a possible intrusion, violation or expropriation of data;

- registration of the users who have been gathering or supplementing new data due to control.

By implementation of the QC-CE-pyramid model at all the levels of quality and information management, we can visualise the position and the role of every level and subject within the construction and function of the information system (Fig. 1).

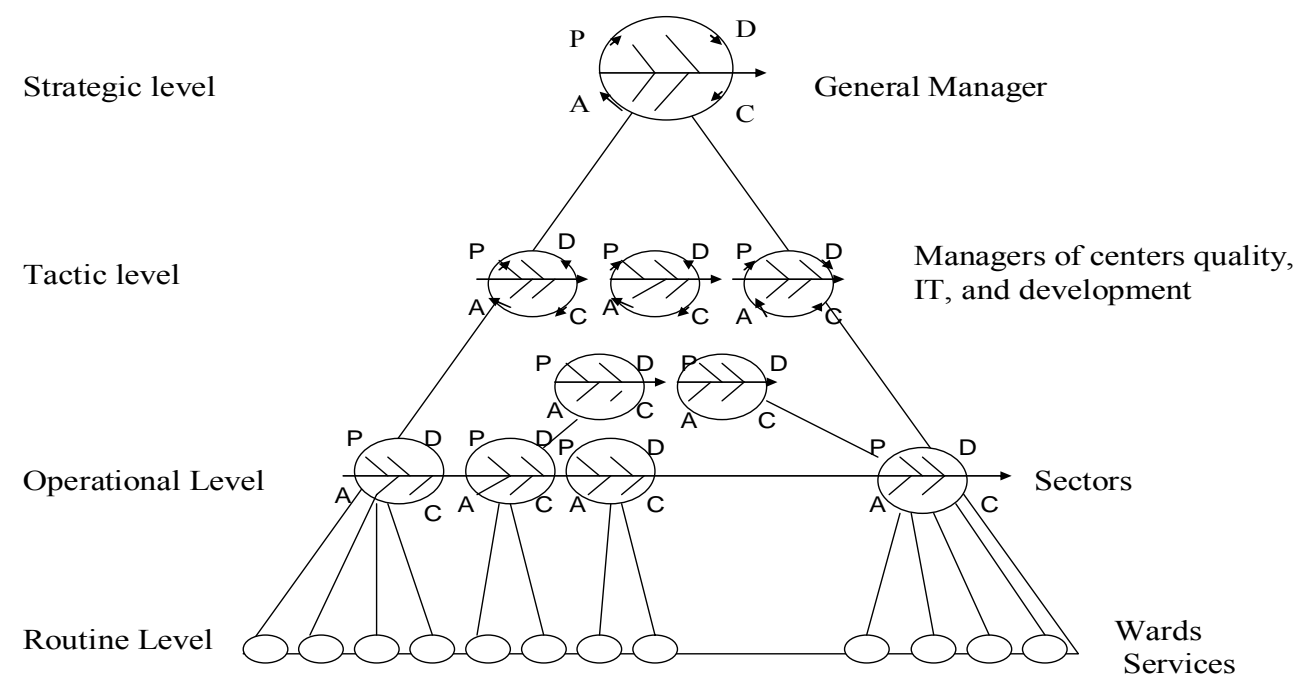

Fig. 1. Implementation of the QC-CE pyramid model in the designing of the informative system within the company

In the hierarchical structure of quality and information management, the number of documents increases from the top to the base, whereas the number of information on quality decreases from the base to the top. The number of information, their character, and the degree of synthesizing of the information depends upon the level of the quality management. The manner and the efficiency of the transfer of information on quality depend upon the range of information, as well as of the delivering time. Therefore, we should build an optimal number of information and documents on the quality for each level and for everyone who inputs information in the system for quality management.

\section{RESULTS AND DISCUSSION}

In the hierarchical structure of quality and information management the priority place is reserved for the leading team of managers, their abilities and knowledge. The strategy management has an obligation to provide decisions regarding the changes which follow the development trends in the world.

We have to take in consideration the capacity of the managers and the employees and the material capabilities of the factory while creating the vision of the factory.

On the second level is the Centre of quality and IT. This is the level where decisions are brought on how the way of work, i.e., re-engineering of the 
business processes $[11,13]$ in order to provide the defined quality with increase the productivity, and lower the costs. The centre for quality and IT manages all the activities. This is the place where multitude of information is collected and analysed, the condition is being evaluated, and further activities are planned upon the forecast. In fact, this is the level where the tasks are realised and checked.

The third level deals with improvement of the business processes communication with the customers, as well as collaboration with the external cooperates, so that the work can be improved. This is where managers of the company's units and services collect and process data. They also function as miniature profit-centres. Actions are being undertaken for quality accomplishment of the tasks with all of the required corrective, servicing and other activities.

At the lowest hierarchical level - the routine performance of the tasks, operations and research units, we place the microprocessors by which we gather data in order to make the initial processing. The conjoining of QC (Quality Circle) approach and the CE (Cause and Effect) diagram in the pyramidal hierarchy at the factory presents a guide to the creation of standard operative procedures.

Standardisation of the processes denotes description and definition of the flows - presented with flow charts, which have their beginning and ending. Every process begins by planning and continues with realisation of the planned activities, after which it is a subject of control in order to prove whatever the planned activity has been realized. The circle closes with the action, which gives answers to the questions: what, who, where, when, and to whom the information is given, accompanied by a complete documentation that specifies the quality, duties, and responsibilities. In order to have an efficient quality, it is not enough just to define it - the quality should be supported by solid documentation $[12,16]$.

Since the quality system defines both the duties and responsibilities of all employees, such data transfer can provide complete care for the quality.

The standard operatiing procedures of the processes in the working unit for travel and freight wagons, begins by the plans and the input information about the initial condition of the wagons (Fig. 2).

The input information refer to achievements of the set targets as: data for incoming wagons which are pending repair, data for the stage of the wagons in the process, additional data for wagons which are in process or pending, purchase orders for the operational process, and evidence of the physical presence within the operational units. Upon the basis of these data, plans and programs have been designed in a way that every employee does his duty and transfers the information both vertically and horizontally.

The output information of the planning presents the input information of the executive system - a point where we manage and coordinate the planned activities. Thus, we gain information on the control over the phases, and the results of the phases in which we find the wagons included in the work, automatic selection of the working wagons, automatic selection of the entrance of the planned working wagons, automatic order of raw materials, spare parts, fabrications and regenerations of the working wagons.

The information of the system for operative performance is input in the control stage. Based upon the check up, we can derive an answer on the process' success and determine the reason which causes discrepancy between the planned and the achieved characteristics. Thus we can suggest corrective measures which are brought back to the planning stage. In the end of the working process we are able to provide information - a report on the quality.

When talking of informational network in a company, it is of great importance to have safety system for protection of the information, in order to avoid their violation [3].

The informational system must be built in a manner which will lower the risks of unauthorised access of external units, accidental errors within the operations, and the input, processing, and the output. Also, the system has to be controlled by the managers, which requires creation of [14]:

- codes for the data-users by setting limits of the data accessibility to some level;

- codes for the data-users by determined limits for entering or altering the data;

- protection against the possible intrusions and violation of the data by registration on behalf of the users;

- control of the: operational system, applications, the input and the output;

- the desired solution comes with the active control of the standards; 
- managers should be well acquainted with the standards and be aware at the same time that if a particular indicator deflects from the standard, the management should make efforts of putting the processes back under control;

- revision of the informational system is required.

During the designing of the system for quality assurance, the transfer of the information should be as fast as possible and as direct as possible, tak- ing care at the same time of the costs derived from the time-waste, correction of incorrectly realised working task, etc. [15].

The informative system for quality assurance based on the QC-CE - pyramid model suggested for the factory for rail vehicles is presented in Figure 3 .

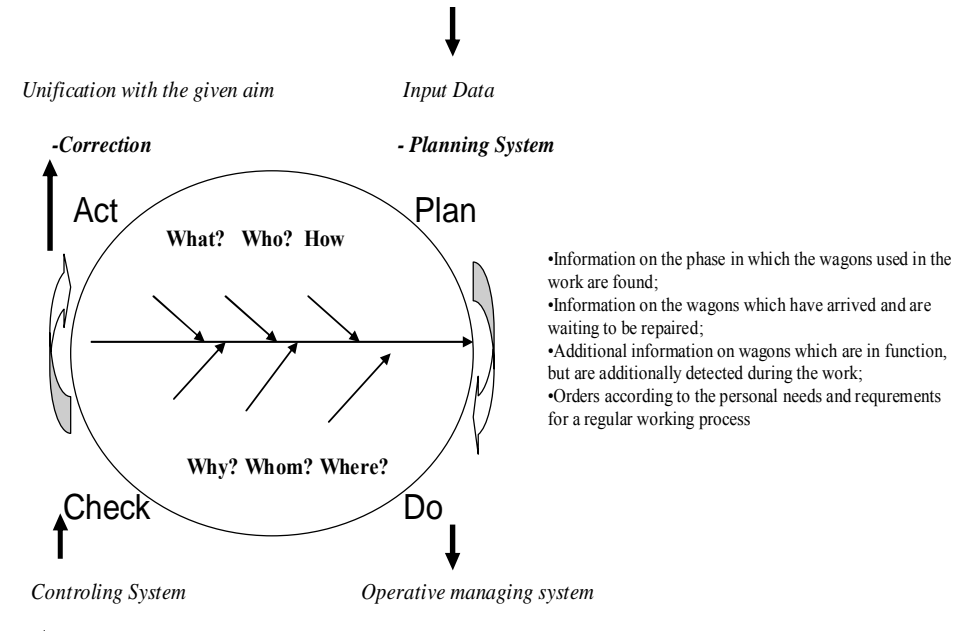

Exit information

By the help of the outgoing information from the wards of the working units for travel and freight wagons, the following is achieved:

-We can review the phases in which the working wagons are found at any time; -Possibility of a long-termed planning of the work range; -Authomatic selection of wagons for work;

Order of entrance of the planned wagons for work;

Physical presence at the working units, in order to achieve optimal exploitation of the units.

Fig. 2. Implementation of the QC-CE-pyramid model in the designing of the information system within the sectors of the working units for travel and freight wagons

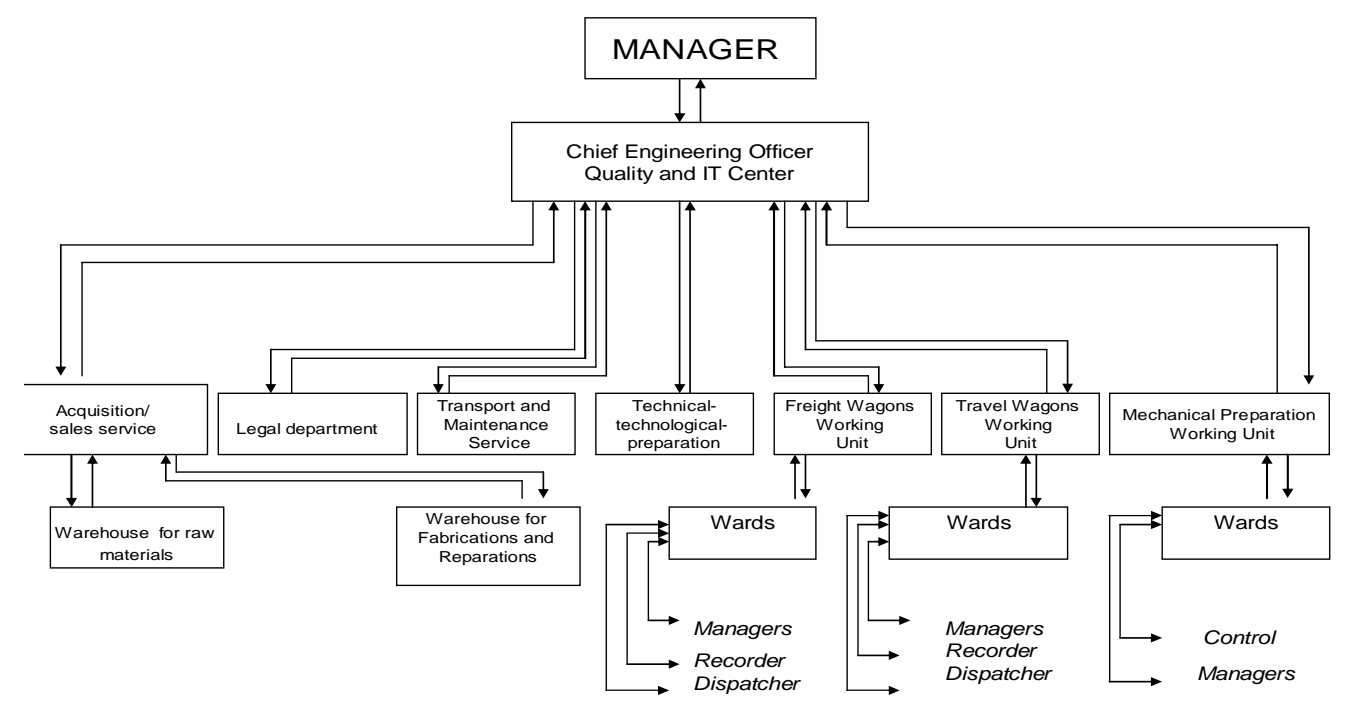

Fig. 3. Suggested resolution for improvement of the informational network by a computer system for governance with the database per sectors the factory's working units 
In this way, we are able to provide the factory with qualitative and quantitative management of the data-base.

\section{CONCLUSION}

Informational systems are of great importance for the provision of quality within the companies, because they present an irreplaceable and useful tool for every manager.

The accurate information delivered on time to the corresponding entities help the managers work more efficiently on the quality.

Out of our practical experience in the Factory for reconstruction and maintenance for rail vehicles, we have assured ourselves that the QC-CE pyramid model makes an excellent foundation for a design of both an efficient and effective informational system. At the same time, this type of a system could provide achievement of the defined quality of work with increased productivity, increased economy, and greater satisfaction of the employees included in the everyday work, also.

Acknowledgment: We express our acknowledgement to the employees of the Factory for rail vehicle, Veles, for the support provided to the former manager eng. Elizabeta Mitreva, in the implementation of the QC-CE-Pyramid model in the designing of the standard's operation procedures, and the quality informative system.

\section{REFERENCES}

[1] T. Conti, Vision 2000: positioning the new ISO 9000 standards with respect to total quality management models, Total Quality Management, 10 (4 \& 5), 454-464 (1999).
[2] V. Chepujnoska, Gj. Chepujnoski, Managing Quality In Practice, Faculty of Economics, Skopje, 1993, pp. 91164.

[3] J. Anttila, Managing and assuring information security in integration with the business management of a company, Information security, Proceedings of the Annual Working Conference on Information Security Management \& Small Systems Security, Vol. 2, IFIP TC 11, ViennaBudapest, 1998.

[4] V. Chepujnoska, Gj. Chepujnoski, Quality Management Basics, Faculty of Economics, Skopje, 1993, pp. 41-159.

[5] H. Weihrich, H. Koontz, Menadžment, 11. izdanje, Mate d.o.o, Zagreb, 1998.

[6] L. W. Rue, L.L. Byars, Management: Skills and Application, Irwin, Burr Ridge; Illinois, 1992, pp. 89-90.

[7] V. Cepujnoska, G. Cepujnoski, Use of QC-CE model in a Total Quality Management, Proceedings of IX International conference for quality assurance, Jerusalem, 1992, p. 699.

[8] V. Chepujnoska, Gj. Chepujnoski, The New Paradigms and the Pyramid Model of the Quality management, Proceedings, 39 EOQ Congress, Lausanne, 1995.

[9] V. Chepujnoska, Gj. Chepujnoski, The strategic management and the QC-CE-PY model, Total Quality Management, 24 (3-4), (1996).

[10] S. K. Laudon, Management Information System, Prentice Hall, 1998.

[11] V. Chepujnoska, G. Chepujnoski, Quality, reengineering and development in the period of tranzition, Contributions, MANU, 231, (1994) (in Macedonian).

[12] ISO 9000/2000.

[13] M. J. Juran, Made in U.S.A.: A renaissance in quality, Harvard Business Review, 71 (4), 42-50 (1993)

[14] C. Parker, T. Case, Management information systems. Strategy and action, Second edition, McGraw-Hill, 1993.

[15] P. Crosby, Let's talk quality: 96 questions that you always wanted to ask Phil Crosby, McGraw-Hill, N.Y., 1989.

[16] B. Dale, R. Boaden, M. Wilcox, R. McQuater, Sustaining total quality management: what are the key issues, The TQM Magazine, 9 (5), 372-9380 (1997). 